\title{
46. MAGNETOSTRATIGRAPHY OF CRETACEOUS AND EARLY CENOZOIC SEDIMENTS OF DEEP SEA DRILLING PROJECT SITE 530, ANGOLA BASIN ${ }^{1}$
}

\author{
B. H. Keating and E. Herrero-Bervera, Hawaii Institute of Geophysics, Honolulu, Hawaii
}

\begin{abstract}
Paleomagnetic studies were conducted on Oligocene to Albian age sediments from DSDP Hole 530A. A sequence of geomagnetic reversals was recorded in the sediments which correspond to seafloor magnetic anomalies 25 to 34 . The lower $300 \mathrm{~m}$ of sediments at this site is characterized by normal polarity and corresponds to the Late Cretaceous magnetically Quiet Interval. Based on the absence of reversals at the bottom of this hole, we suggest that the basal sediments are no older than latest Albian. If there is no major discontinuity at the base of Hole 530A, the age of the seafloor can be inferred to be close to the onset of the Cretaceous Quiet Interval-that is, slightly less than 110 m.y.
\end{abstract}

\section{INTRODUCTION}

Paleomagnetic studies were conducted on Mesozoic and early Cenozoic sediments of Deep Sea Drilling Project (DSDP) Hole 530A. These studies outlined a polarity sequence for this site which was subsequently correlated with the polarity sequence of nearby DSDP holes. The magnetostratigraphy of the Late Cretaceous has been established through studies of DSDP cores (Keating and Helsley, $1978 \mathrm{a}, \mathrm{b}, \mathrm{c} ;$ 1979), land sections (Lowrie and Alvarez, 1977; Butler and Lindsay, 1980; Lindsay et al., 1981), and the magnetic anomalies observed in the seafloor (LaBrecque, et al., 1977; Ness et al., 1980). The correlation of magnetic polarity epochs at Hole 530A to the geomagnetic time scale proved extremely useful in establishing age constraints for this hole because much of the Mesozoic strata collected was barren or contained long-ranging microfossils which yielded few biostratigraphic controls.

\section{GEOLOGIC SETTING}

Hole $530 \mathrm{~A}$ is located at $19^{\circ} 11.26^{\prime} \mathrm{S}, 9^{\circ} 23.15^{\prime} \mathrm{E}$ in the South Atlantic Ocean. The site is situated at the southeastern corner of the Angola Basin, $20 \mathrm{~km}$ north of the Walvis escarpment near the eastern end of the Walvis Ridge (see Fig. 1), but is not on a distinct magnetic lineation. Within this basin several magnetic lineations are apparent, which parallel the coast line of Africa. Sibuet et al. (in prep.) identified the sequence of anomalies as M2 through M7, which would suggest an age of late Hauterivian to early Barremian. Alternatively, Cande and Rabinowitz (1978) have suggested that the Angola Basin anomalies represent a ridge jump, which occurred in the early Aptian, about Anomaly M0 time or later.

\section{LITHOSTRATIGRAPHY}

The sediments at Site 530 were divided into eight lithologic units which are described in the Site 530 sum-

\footnotetext{
${ }^{1}$ Hay, W. W., Sibuet, J.-C., et al., Init. Repts. DSDP, 75: Washington (U.S. Govt.
}

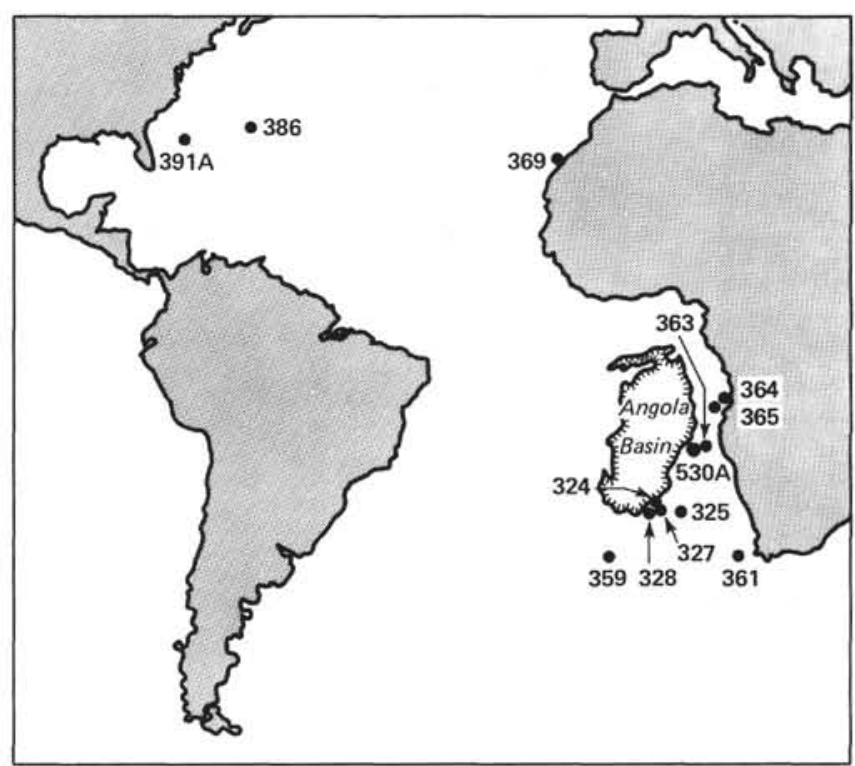

Figure 1. Map of the Atlantic Ocean showing positions of drill sites cited in text.

mary chapter, this volume. Sediment Units 3 through 8 were sampled as well as basaltic basement. Unit 3 (Cores 17-36) consists of Oligocene red to green mudstones with some carbonate mixtures with clay (mudstonemarlstone). Unit 4 (Cores 37-50) consists of Eocene to Maestrichtian multicolored mudstone, marlstone, chalk, and clastic limestone. This unit is dominantly green with alternating red beds. It is underlain by Unit 5 (Cores 51-70), which consists of Maestrichtian dark green mudstone, marlstone, clastic limestone, and siliciclastic sandstone. Carbonate clastic debris and volcanic sandstones are found in Cores 69 and 70. Large fragments of Inoceramus are present in this unit. Unit 6 (Cores 71-75) consists of Campanian volcanogenic sandstones which are dark green to green-black. These sands occur as graded turbidites of variable thickness.

Unit 7 (Core 75, Section 3 to Core 86) consists of red claystone interbedded with green, red, and purple silt- 
stone. There are numerous turbidite sequences within this unit. However most are 1 to $2 \mathrm{~cm}$ thick. These thin turbidites are green in color as a result of iron reduction. Green halos occur around the thin siltstone layers of turbidities and laminae in some dominantly red claystone beds. Unit 8 (Cores 87-105) consists of red and green claystone and marlstone with interbedded black shale. Pyrite is commonly found associated with the green and black shales as disseminated crystals and as large aggregates (see Site 530 summary chapter for more details).

\section{BIOSTRATIGRAPHIC CORRELATIONS}

Within the Cenozoic sediments of Hole 530A, there is good fossil control on the age of the rocks. Biostratigraphic control is briefly discussed here; for more detail refer to Steinmetz and Stradner, this volume. Five normal polarity epochs are identified within Cores 40 through 50. The late Paleocene nannofossils of Zones NP8 and NP9 are identified from the core catchers of Cores 40 to 43 . Within the core catchers $40, C C$ to $41, C C$, Discoaster multiradiatus zone fossils were present, with $D$. multiradiatus and D. lenticularis common. Nannofossils of Zone NP8 were identified in 42,CC and 43,CC. Fossils from 44,CC to 47,CC were identified as belonging to nannofossil Zones NP6 and NP5. The early Paleocene Ellipsolithus macellus Zone NP4 was not identified in the core catcher samples. Fossils of NP3 were recognized within $48, C C$ which corresponds to normal polarity. The Markalius inversus Zone, NP1, was identified just above the Cretaceous/Tertiary boundary. Significant reworking of Cretaceous species occurs within Core 50. The first occurrence of Cretaceous nannofossils occurs at a depth of 52 to $53 \mathrm{~cm}$ in Section 2, Core 50 . Thus, the boundary as identified by microfossils lies within $10 \mathrm{~cm}$ of the polarity change at the end of the Cretaceous. As you examine the biostratigraphy, downhole horizon markers are sparse. The species found for the most part are long-ranging species. Thus there is very little control on stage boundaries and there are no specific correlations with polarity boundaries.

In the interval from Core 50, Section 2, $10-14 \mathrm{~cm}$ to Core 61, one or two specimens of Abathomphalus mayaroensis Bolli, Globotruncana gagnebini Tilev, G. contusa (Cushman), G. fornicata Plummer, G. arca Cushman, Pseudotextularia difformis (Kikoine), and Rugoglobigerina were found. In Cores 76 through 80 , simple and early globotruncanids were found, such as $G$. arca. G. fornicata, G. linneiana, and $G$. venticosa White. The interval from Cores 77 to 80 could be lower Campanian to late Santonian, but not significantly older (McNulty, this volume). In Cores 81 through 86 , whether rare or common, the planktons were dominated by Marginotruncana pseudolinneiana Pessagno and M. sinuosa Porthault. In Cores 93 through 95 Dicarinella canaliculata (Reuss), D. imbricata (Mornod), Marginotruncana pseudolinneiana Pessagno, and $M$. coronata (Bolli) are prominent representatives of globotruncaniforms. Hedbergella delrioensis (Carsey), H. hoezli (Scheibnerova), $H$. simplex (Morrow) are typical hedbergellids. Within Cores 96 to 105 planktonic foraminifers were rare. One sample at 104-2,
49-52 $\mathrm{cm}$ was dominated by hedbergellids, including Hedbergella infracretacea (Glaessner), $H$. libyca Barr, H. planispira (Tappan), and G. simplex (Morrow).

Biostratigraphy based on calcareous nannofossils is given in Stradner and Steinmetz, this volume.

\section{PALEOMAGNETIC SAMPLING}

Approximately 500 samples were collected from Cores 35 through 108 using a sampling interval of approximately $35 \mathrm{~cm}$ within the Cretaceous age portion of the core. Only consolidated samples were collected. Over much of this interval recovery was variable, averaging $57 \%$. The stratigraphic gaps resulting from poor core recovery limited the usefulness of Hole $530 \mathrm{~A}$ for definition of a detailed Cretaceous reversal sequence, particularly within the Maestrichtian portion of the stratigraphic section. However, because the biostratigraphic controls were scarce, the reversal stratigraphy proved extremely useful in constraining the age of the Mesozoic strata in this hole.

\section{PALEOMAGNETIC STABILITY TESTS}

The natural remanent magnetization (NRM) of each sample was initially measured on board the Glomar Challenger. Because the NRM intensities of many of the shale units do not exceed the noise level of the shipboard magnetometer, the samples were again measured at the University of Hawaii using a ScT cryogenic magnetometer.

Progressive alternating field demagnetization experiments were carried out on a pilot group of samples consisting of at least one of each characteristic lithology. The results of some of these demagnetization experiments are shown in Figures 2 and 3. The lithology of the pilot study samples shown in Figures 2 and 3 consists of nannofossil oozes $(2-3,98 ; 3-3,73 ; 12-1,110)$, green mudstones $(51-1,145 ; 88, C C(8 \mathrm{~cm}) ; 63-2,65 ; 25-2,13)$, brown claystone $(50-2,13 ; 82-2,42)$, green volcanic sandstone $(71-2,135)$, red claystone $(79-4,89)$, and black claystone $(96-4,66 ; 95-5,3)$. Samples $25-2,13$; $50-2,13 ; 63-2,65 ; 79-4,39 ; 82-2,92 ; 88, C C(8 \mathrm{~cm})$; $95-5,3$; and $96-4,66 \mathrm{~cm}$ are very representative of the dominant lithologies observed in this core. The demagnetization characteristics illustrated in Figures 2 and 3 are representative of the various rock units sampled. The pilot study samples were demagnetized at 2.5 and 5 $\mathrm{mT}$ steps up to 15,50 , or $100 \mathrm{mT}$ alternating fields (1000 $\mathrm{Oe}=100 \mathrm{mT}$ ). Demagnetization was discontinued when the remaining magnetic moment reached $10 \%$ of its initial value or when the magnetic moment of the sample became comparable to the noise level of the instrument.

All of the pilot samples show marked loss of magnetic moment at fields less than $25 \mathrm{mT}$, indicating that most of the magnetization is contained in carriers of low to medium coercivity. The mean destructive field for the pilot group was $13.5 \mathrm{mT}$. By 10 to $25 \mathrm{mT}$ many samples were reduced to only 10 to $20 \%$ of the natural remanent magnetization. Observation of the demagnetization plots, however, show that in most cases these samples are directed toward the origin, after $5 \mathrm{mT}$ applied field, and thus the secondary component has been removed in fields of 7.5 to $10 \mathrm{mT}$. 


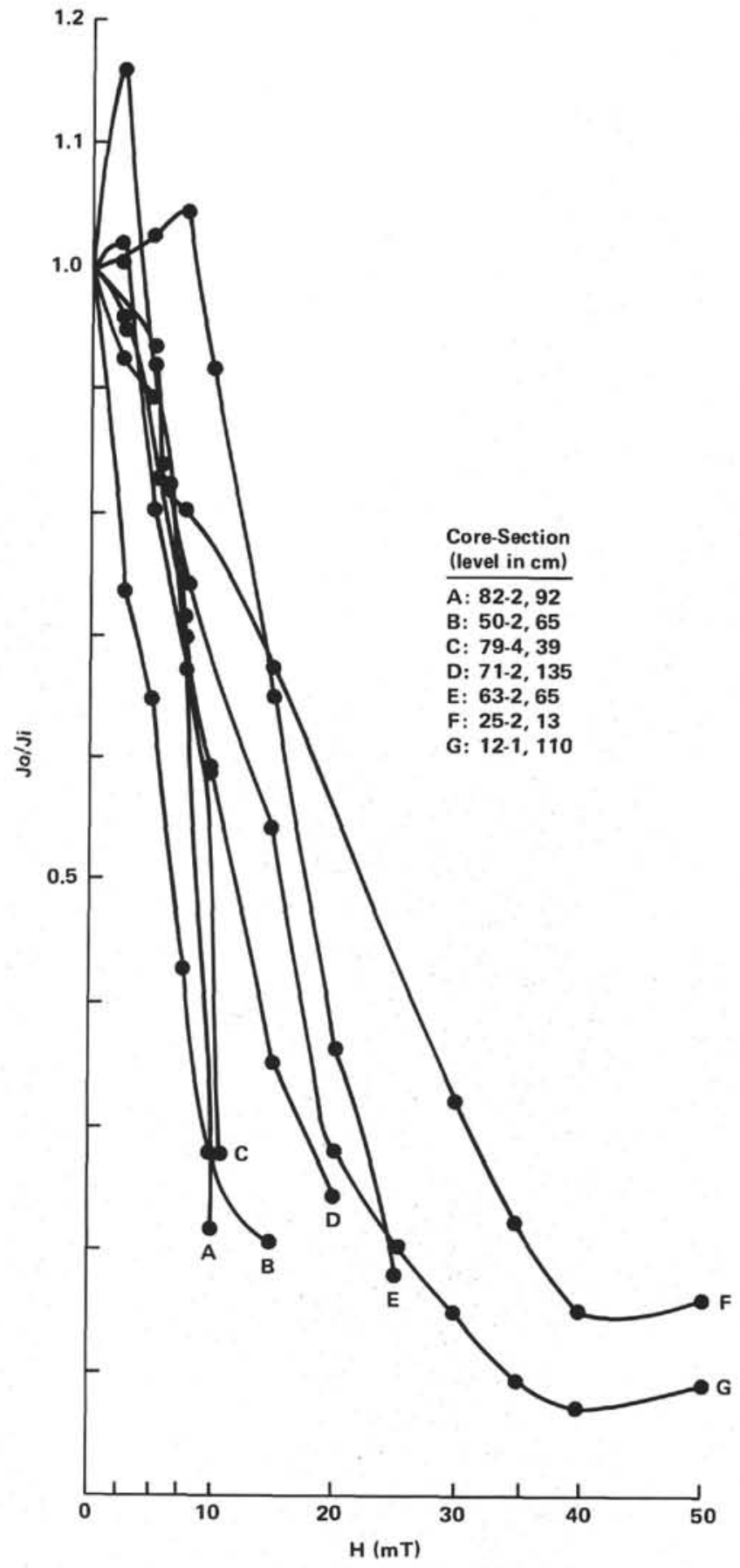

Figure 2. Demagnetization curve showing the change in intensity on demagnetization for "pilot study" samples.

Examples of the magnetic behavior of stably magnetized samples are shown in Figure 3. The majority of the samples studies are directionally stable, displaying only a few degrees of change after demagnetization. The orthogonal plots clearly show movement toward the origin of the diagram and stable remanence. Higher demagnetization fields, however, often were not employed since the initial magnetization was extremely weak, especially in the case of the nannofossil ooze and green claystone lithologies. Our previous studies prove that numerous weakly magnetized samples will acquire spurious moments (acquired in laboratory fields) when demagnetized to less than $10 \%$ of their original moment. To avoid this problem, we discontinued demagnetization studies when the samples reached $10-15 \%$ of the original magnetic moment.

Isolated samples did show significant changes on demagnetization, and these changes were dominantly in declination with very little change in inclination. By rejecting samples which display more than $15^{\circ}$ of directional change, we have used a very effective filter which eliminates samples with strong secondary or viscous components of magnetization. Thus, even though many of these samples are initially quite weakly magnetized and thus cannot be demagnetized to a high degree, a stable endpoint direction has generally been identified, and the directional data shown in Figure 4 should be considered reliable.

In order to assess the magnetic polarity sequence, the alternating field demagnetization results were plotted stratigraphically in Figure 4 . This figure shows the demagnetized inclinations with single sample polarity inversions removed. These single sample polarity inversions, when examined in previous studies, have frequently proven to be inversions of samples which occurred during shipboard sampling. The first stratigraphic plot, Figure 4, shows the paleoinclination data from all samples collected minus single sample polarity inversions. The second stratigraphic plot, Figure 4, illustrates the paleoinclinations from the most stably magnetized samples. The results from samples displaying in excess of $15^{\circ}$ of motion in either inclination or declination have been omitted.

The paleomagnetic polarity sequence that results from Hole $530 \mathrm{~A}$ is summarized in the block diagram to the right in the same figure (black = normal polarity; white $=$ reversed polarity). The reversal sequence is a combination of the two stratigraphic plots. From the Cretaceous/Tertiary boundary (Core 50) downward in the hole, only the selected, more stably magnetized data were used in determining the polarity stratigraphy. However, since sampling was so sparse in the Cenozoic portion of the hole (the study of this portion of the hole was used at sea to confirm the age of core) we have elected to use the larger data set to interpret the Cenozoic reversal sequence. Comparison of selected and unselected data produces a reversal sequence easily correlated with the geomagnetic time scale.

\section{MAGNETOSTRATIGRAPHIC CORRELATIONS}

The magnetostratigraphic correlations for Hole 530A are obvious for all of the hole, except for the interval from Core 68 to 80 . It is easiest to examine the magnetic stratigraphy by starting at the bottom of Hole 530A. The bottom $300 \mathrm{~m}$ of sediment at this hole are characterized by negative magnetic inclinations. Since this site is situated in the southern hemisphere, these negative inclinations represent normal polarity of the Earth's magnetic field. Based upon the biostratigraphy, this interval ranges in age from late Albian or early Cenomanian to 

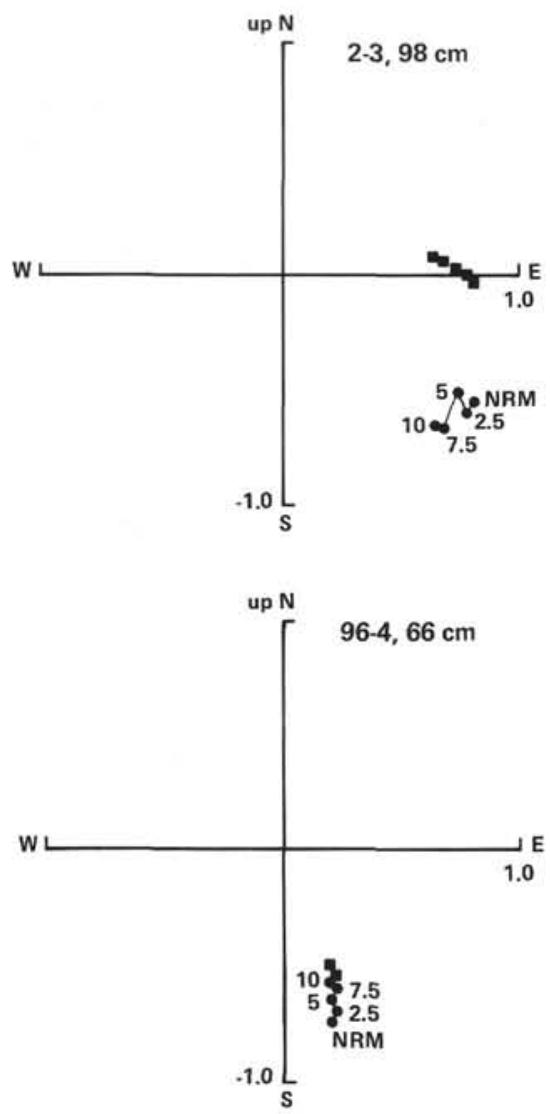
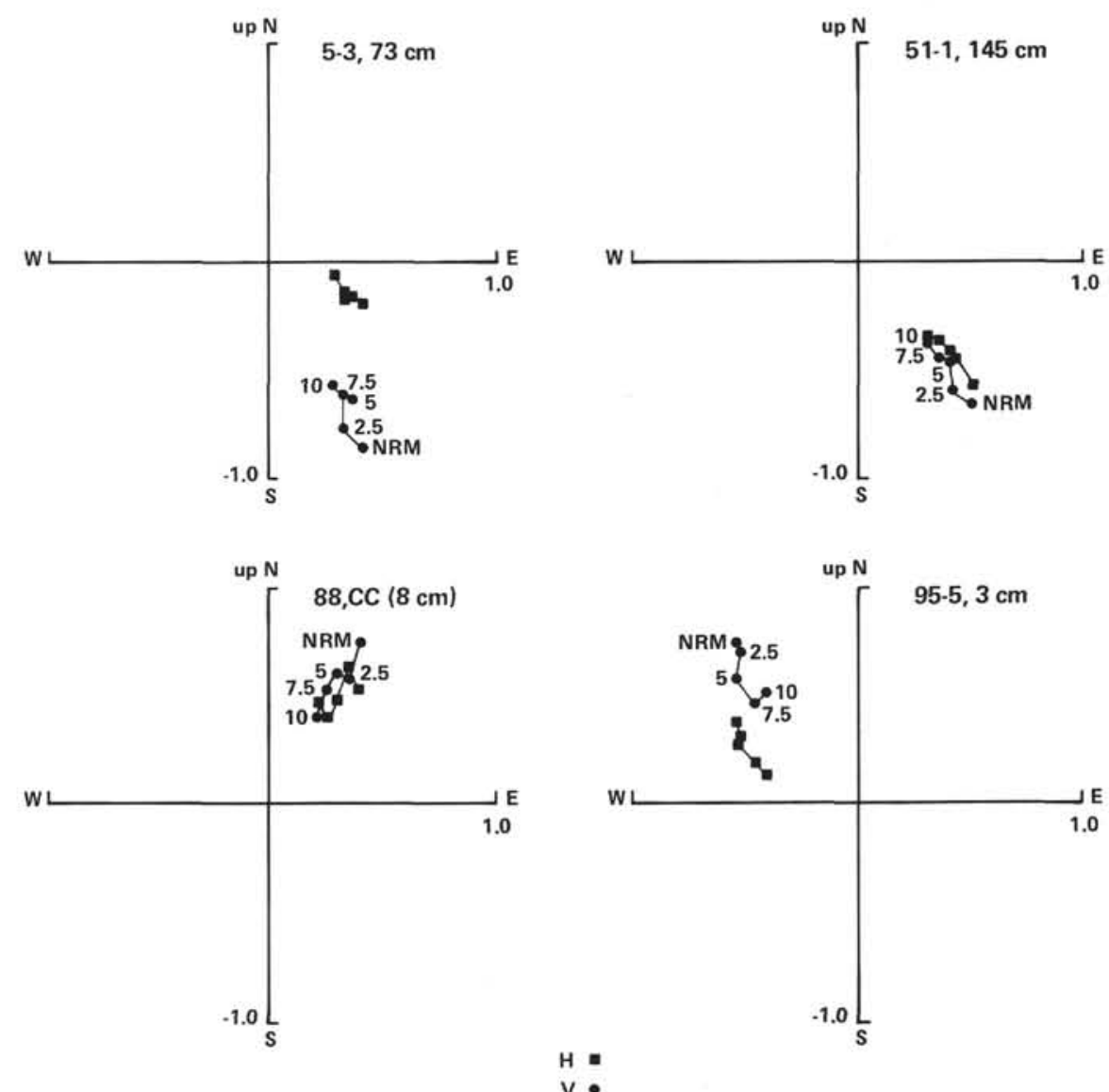

Figure 3. Orthogonal projections of the magnetization vector through progressive alternating field demagnetization. The numbers indicate the demagnetization level in $\mathrm{mT}$. The squares represent projections on the horizontal plane, and the circles represent projections on the north-south vertical plane.

Coniacian ${ }^{2}$. Previous magnetostratigraphic studies, notably those of Helsley and Steiner (1969), have identified this interval as a magnetically "Quiet Interval." The interval is characterized by normal polarity with only brief reversed events identified (Keating et al., 1974). As we move upward in the hole, omitting the interval between Cores 80 and 68 , to be discussed later, we see that there are only two normal polarity intervals of Maestrichtian age. However six magnetic anomalies of this age have been identified on the seafloor. Using the relative thickness or duration of these polarity zones, we correlate the normal interval between Cores 68 to 59 to seafloor anomaly 33. Subsequent anomalies are numbered in order up to Core 53. Because there is a sampling hiatus between Cores 51 and 53 , we suspect that at least one reversed polarity zone is missing at this point. We suggest the normal polarity zone recognized in Core 51 is correlatable with seafloor magnetic anomaly 30 . Seafloor anomalies 29 through 25 can be correlated with the reversals of Paleocene age in Cores 49 through 40 (see Fig. 5). Because of the scarcity of samples within the Oligocene sections of the core, however, no correlation has been attempted.

\footnotetext{
2 Revisions of the stratigraphic ages are given in Steinmetz et al., this volume.
}

\section{TURBIDITE UNITS IN CORES 68 TO 80}

The interval from Cores 68 to 80 contains abundant turbidite sequences. Cores 68 to 70 of lithologic Unit 5 contain coarse-clastic interbeds, mainly of an interlamination, or massive mixtures of dark gray siliciclastic sand and light green volcanogenic sand. These sandstone beds result from massive transportation of sediments down the continental slope.

The dominant rock type within Cores 71 to 75 (Unit 6) is volcanogenic sandstone. Complete Bouma turbidite sequences are common throughout this interval. The turbidites are variable in thickness, and they become progressively less abundant below Unit 6 . Within Cores 76 to 80 of lithologic Unit 7, turbidites are still present, but their thickness decreases to 2 to $30 \mathrm{~cm}$. Downward in the hole, the thickness of turbidites decreases further, and the grain size of the coarse grained portion also decreases. By $866 \mathrm{~m}$ depth (base of Core 78) most turbidites consist of green siltstone at the bases of reddish claystone sediment cycles. In Cores 79 and 80 , the turbidites are reduced to 1 and $2 \mathrm{~cm}$ thickness.

Turbidites in general are not suitable for magnetostratigraphic studies for two reasons. First, they represent disrupted sediments which have been moved by mass transport down slope from their original site of de- 


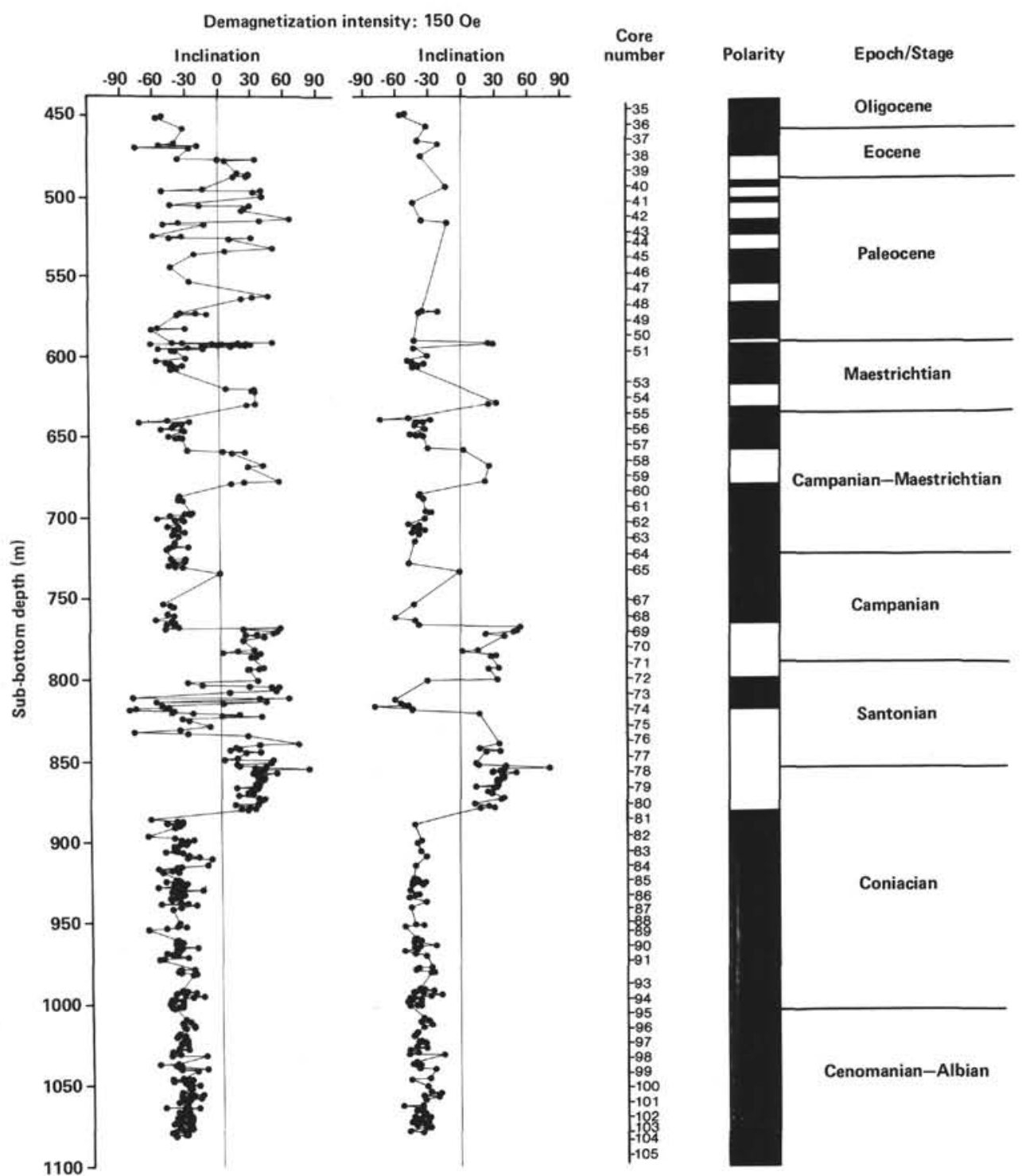

Figure 4. Plots of demagnetized $(15 \mathrm{mT})$ sample inclinations and intensities versus depth, Hole 530A. Unselected data are plotted in the column to the left. Selected data, i.e., data from more stably magnetized samples are plotted in the column to the right. Depths below seafloor are on the vertical scale. A summary reversal sequence column is plotted to the far right. In this column, reversed polarity is represented by white, while normal polarity is illustrated by black shading. The ages determined on the basis of microfossils are shown at the far right.

position and may contain fossil remains with ages greatly different from the original depositional age. Secondly, the coarse sandstones within turbidite units tend to be magnetically unstable as a result of the larger magnetic grain size. However, in the case of Hole 530A, a third characteristic of turbidites may be even more important, and that is the episodic nature of deposition. Since turbidites represent catastrophic depositional events, they are thick units of sediments deposited in extremely limited periods of geologic time. For this reason, it is doubtful that the magnetic record preserved by a massive turbidite unit, such as Hole 530A, Cores 68 to 80 , should be considered "representative" of a geologic stage or stages. Instead such units could represent stratigraphically thick but chronostratigraphically isolated records of geologic time. Taking this circumstance into consideration, it is possible that the magnetic stratigraphy observed in Cores 68 to 80 could be disproportionate in thickness or even have missing time and thus not be a true representation of the Earth's magnetic field behavior. If we examine the results from the most stably magnetized samples, however (see Fig. 4B), we find that the interval of the hole characterized by turbidites is marked by two reversed polarity intervals separated by a brief normal polarity interval. This is the same polarity sequence identified elsewhere in deep sea sediment cores of early Campanian age. The thickness of the polarity units is, however, not comparable to that observed elsewhere. Thus, despite the desultory nature of deposition, the turbidite unit appears as a whole to be magnetized systematically in the true paleofield direction. This is logical if the magnetization in the stably 


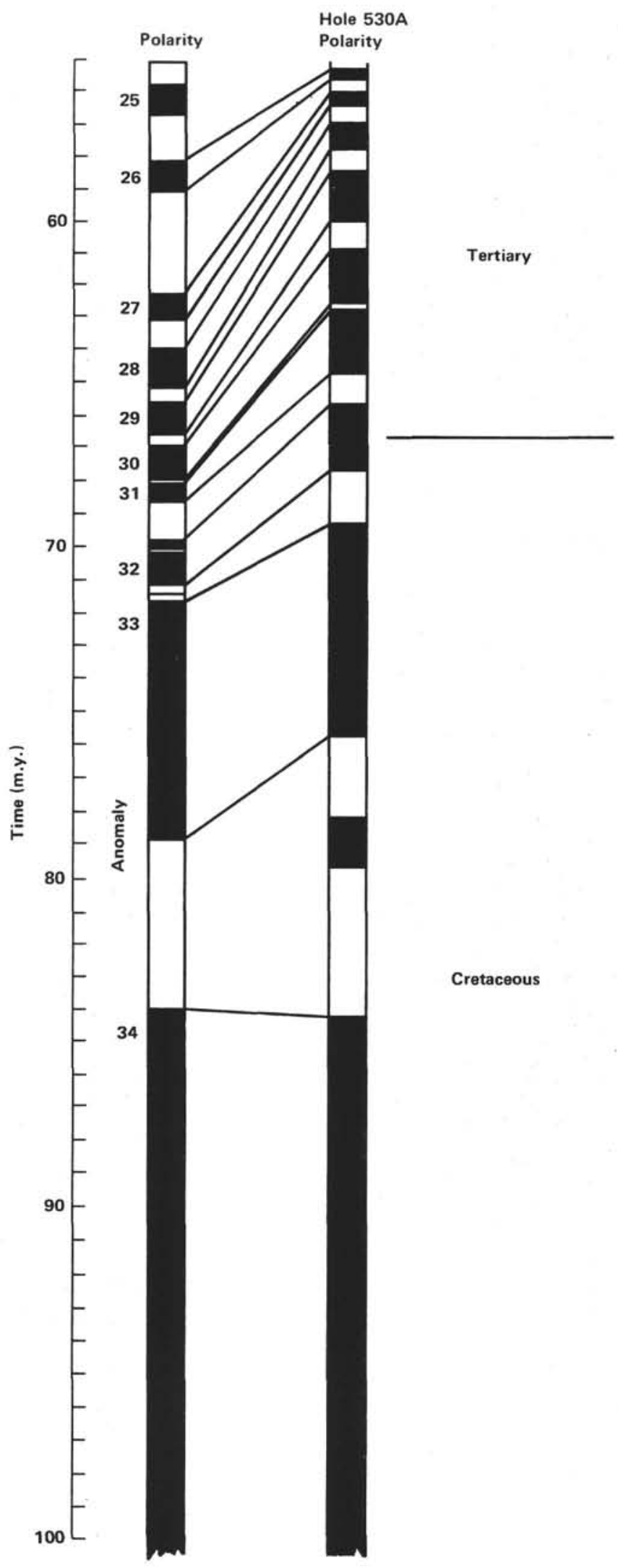

Figure 5. Correlation of the Leg 75 magnetic results (Hole 530A, shown at right) with the geomagnetic reversal sequences derived at sea from seafloor magnetic anomalies and those reported from Gubbio, Italy (Lowrie et al., 1980). magnetized samples is carried by the finest grain size sediments of the turbidite unit. By removing the unstably magnetized samples from the data set, it appears that we have identified the true polarity sequence characteristic of the Campanian field that only needs to be corrected for the anomaly in sedimentation rate produced by the presence of turbidite deposition.

\section{PALEOLATITUDE DETERMINATIONS}

Using the paleomagnetic inclinations measured within the sediments of Hole $530 \mathrm{~A}$, it is possible to calculate the paleolatitude of this site through time. The latitude which is calculated based upon the dipole formula allows us to place constraints on the tectonic development of the South Atlantic basin. The results of the paleoinclination determinations are summarized in Table 1. The paleoinclinations decrease as one moves up the core. The mean paleolatitude for the Coniacian sediments was $22.45^{\circ}$ while the mean for the Eocene sediments was only $15.55^{\circ}$. This slight shallowing of inclination up-hole, however, is probably not significant tectonically. The shallow inclinations for the Eocene and Paleocene occur in statistically small data sets with large scatter.

\section{DISCUSSION}

Hole 530A is one of numerous DSDP holes studied in an attempt to construct a paleomagnetic reversal sequence for the Cretaceous. Sites previously studied include $363,364,365,324,325,327,328,359$, and 361 . The magnetostratigraphy of four Atlantic DSDP legs$40,41,43$, and 44 -has been summarized by Keating and Helsley (1978c) and provides the reference framework for the age assignments made above. The results obtained from the Hole 530A cores are compatible with those of Keating et al. (1975a) and Keating and Helsley (1978b) and show that the Maestrichtian is characterized by mixed polarity, whereas the Campanian is dominantly normal with reversed polarity zones only near the upper and lower boundaries. The upper Campanian reversed polarity in Hole $530 \mathrm{~A}$ is an extension of the Maestrichtian mixed polarity sequence, and the two reversals found near the Campanian/Santonian boundary are probably the same as those reported by Keating et

Table 1. Paleomagnetic inclinations measured within the sediments of Hole $530 \mathrm{~A}$.

\begin{tabular}{|c|c|c|c|c|c|}
\hline Cores & Age & $\begin{array}{c}\text { Mean } \\
\text { paleo- } \\
\text { inclination } \\
\text { (degree) }\end{array}$ & $\begin{array}{l}\text { Standard } \\
\text { deviation }\end{array}$ & $\begin{array}{l}\text { No. of } \\
\text { samples }\end{array}$ & $\begin{array}{l}\text { Paleo- } \\
\text { latitude }\end{array}$ \\
\hline $37-39$ & $\begin{array}{l}\text { Oligocene to } \\
\text { Eocene }\end{array}$ & 29.11 & 20 & 13 & 15.55 \\
\hline $40-49$ & Paleocene & 31.75 & 17 & 47 & 17.19 \\
\hline $50-67$ & $\begin{array}{l}\text { Paleocene to } \\
\text { Campanian }\end{array}$ & 35.35 & 13 & 91 & 19.52 \\
\hline $68-80$ & Campanian & 35.78 & 18 & 109 & 19.80 \\
\hline $81-94$ & $\begin{array}{l}\text { Santonian to } \\
\text { Coniacian }\end{array}$ & 39.59 & 10 & 106 & 22.45 \\
\hline $95-105$ & $\begin{array}{c}\text { Turonian to } \\
\text { Albian }\end{array}$ & 35.25 & 7 & 96 & 19.46 \\
\hline
\end{tabular}


al. (1975b). The two reversals in the lower Campanian to Santonian portion of Hole 530A occur as a pair surrounded by long intervals of normal polarity. Very little can be said about the polarity of the Santonian through Cenomanian materials recovered from Legs 40 through 44 , for little sediment of these ages was recovered on these legs (see Fig. 6). Previous studies by Keating (1976) and by Helsley and Steiner (1969) indicate that this interval is characterized by normal polarity. The observations from this site are consistent with those of DSDP Legs 40 through 44 , with the exception of a few reversed samples occurring near the Turonian/Cenomanian boundary at Site 361. A reversed polarity event has been observed elsewhere in DSDP material (Keating, 1976) at this boundary, and a similar event may have been observed on land by Shive (pers. comm.). However, no evidence of this magnetic reversal is preserved at Hole 530A.

One can summarize the pre-Cenomanian work by saying that mixed polarity is present throughout the Lower Cretaceous and is first encountered near the Lower/Upper Cretaceous boundary. Again, these observations are compatible with those by others, e.g., Helsley and Steiner (1969), Irving and Couillard (1973), and Lowrie et al. (1980). The results from Hole 530A suggest that no Lower Cretaceous sediments of mixed polarity are present. Thus it is likely that the age of the sediments at the base of Hole 530A are no older than latest Albian (approximately 110 m.y.).

\section{CORRELATION WITH SEAFLOOR MAGNETIC ANOMALY SEQUENCE}

Ness et al. (1980) published a synthesis of marine magnetic and magnetostratigraphic time scales to 90 m.y., demonstrating that the time scales for marine anomalies vary significantly. The Cretaceous magnetic time scales that Ness and his colleagues critiqued are not polarity time scales based upon magnetostratigraphic correlation, but are instead sequences derived from seafloor anomalies using different spreading rates. While the time scales derived through seafloor anomaly analysis and magnetostratigraphic studies are similar, the latter preserve much more detail of polarity changes.

Within the Eocene to Paleocene section of Hole 530A, there are repeated reversals of the field. We suggest that this section of the core corresponds to seafloor magnetic anomalies 25 to 29 (see Fig. 5). Within the Maestrichtian to Campanian sediments (Cores 50-59; Fig. 4), only three intervals of reversed polarity can be identified. Based upon previous paleomagnetic studies, more polarity epochs should be present within this interval. Hiatuses resulting from poor recovery and gaps in sampling resulting from deformation of sediments particularly at $600 \mathrm{~m}$ depth (Core 52) and at $630 \mathrm{~m}$ depth (between Cores 54 and 55) may be very significant and contribute to the correlation problem. The interval from 680 to 760 $\mathrm{m}$ depth of this core is dominantly normal polarity. We suggest that this interval correlates with the early to late Campanian normal polarity zone seen in Figure 5 and correlates with anomaly 34 .

Several polarity changes observed in the unselected data at depths of 760 to $880 \mathrm{~m}$ in Hole $530 \mathrm{~A}$ do not cor- relate with the geomagnetic time scale. Two reversed intervals have been reported in the early Campanian by Keating and Helsley (1978b), and Alvarez and Lowrie (1978) report one. For the reasons explained earlier we were dubious about the apparent reversals in Hole $530 \mathrm{~A}$, Cores 68 to 80,760 to $880 \mathrm{~m}$ depth. We have attempted to select the most stably magnetized results for correlation purposes. By doing so, we have derived a polarity transition sequence which does correlate well with the early Campanian events shown in Figure 6.

No paleomagnetic reversals have been identified within the older sediments of this hole. Cores 81 through 104 are characterized by normal polarity. We correlate this portion of the core with the Late Cretaceous Quiet Interval. Since none of the brief reversals recorded at Sites $386,361,363$, or 364 has been identified near the base of the sediment pile at Hole 530A, we conclude that we have not sampled Albian sediments or that only the uppermost Albian sediments are represented at this site, for the mid- to lower Albian mixed polarity interval is not present.

\section{SUMMARY AND TECTONIC IMPLICATIONS}

Paleomagnetic studies of sediments from DSDP Hole 530A have yielded a sequence of reversals of Eocene to Cenomanian age which correlate well with seafloor anomalies 25 to 34 . With the exception of the cores of a turbidite unit at a depth of 760 to $880 \mathrm{~m}$, the remainder of this core is characterized by normal polarity. We correlate this long interval of normal polarity from 680 to $1070 \mathrm{~m}$ depth with the Cretaceous Quiet Interval. Based upon the magnetic reversal stratigraphy, we suggest that the oldest sediments at this site are Cenomanian to latest Albian. Given the absence of reversals within the lowermost portions of this hole, it seems unlikely that we have sampled any early or middle Albian sediments. Assuming that the age of the basal sediments in Hole 530A is approximately the age of the seafloor basalts, the absence of reversals in the basal sediments supports the Cande and Rabinowitz (1978) hypothesis that a ridge jump is present in the Angola Basin and that the age of the crust is approximately that of magnetic anomaly M0. If the age assignments suggested by Sibuet et al. (in prep.) were correct, then several magnetic reversals should be present within the basal sediments of this hole. No reversed polarity intervals were found, however; thus, this hypothesis is probably invalid.

\section{ACKNOWLEDGMENTS}

We would like to thank C. E. Helsley and W. W. Sager for their critical review of this manuscript. Hawaii Institute of Geophysics contribution no. 1418 .

\section{REFERENCES}

Alvarez, W., and Lowrie, W., 1978. Upper Cretaceous paleomagnetic stratigraphy at Moria (Umbrian Appenines, Italy): Verification of Gubbio section. Geophys. J. Roy. Astron. Soc., 55:1-17.

Butler, R. F., and Lindsay, E. H., 1980. Magnetostratigraphy, biostratigraphy and geochronology of Cretaceous-Tertiary boundary sediments, Red Deer Valley. Nature, 284:375-376.

Cande, S., and Rabinowitz, P. D., 1978. Mesozoic seafloor spreading bordering conjugate continental margins of Angola and Brazil. Proc. Offshore Tech. Conf.: Houston (Rep. OTC 3268), pp. 1869-1876. 
Helsley, C. E., and Steiner, M. B., 1969. Evidence for long intervals of normal polarity during the Cretaceous period. Earth Planet. Sci. Lett., 5:325.

Irving, E., and Couillard, G. W., 1973. Cretaceous normal polarity interval. Nature Phys. Sci., 244:10.

Keating, B. H., 1976. Contribution to Paleomagnetism [Ph.D. dissert.]. University of Texas at Dallas.

Keating, B. H., and Helsley, C. E., 1978a. Magnetostratigraphic studies of Cretaceous sediments from DSDP Site 369. In Lancelot, Y., Siebold, E., et al., Init. Repts. DSDP, 41: Washington (U.S. Govt. Printing Office), 983-986.

1978b. Magnetostratigraphy of Cretaceous age sediments from Sites 361, 363, 364, and 365. In Bolli, H. M., Ryan, W. B. F., et al., Init. Repts. DSDP, 40: Washington (U.S. Govt. Printing Office), 459-467.

1978c. Paleomagnetic results from DSDP Hole $391 \mathrm{C}$ and the magnetostratigraphy of Cretaceous sediments from the Atlantic Ocean floor. In Benson, W. E., Sheridan, R. E., et al., Init. Repts. DSDP, 44: Washington (U.S. Govt. Printing Office), 523-528.

1979. Magnetostratigraphy of Cretaceous sediments from DSDP Site 386. In Tucholke, B., Vogt, P., et al., Init. Repts. DSDP, 43: Washington (U.S. Govt. Printing Office), 781-784.
Keating, B. H., Helsley, C. E., and Pessagno, E. A., Jr., 1974. Late Cretaceous reversals. EOS, Trans. Am. Geophys. Union, 55:236. $75-79$. 1975a. Late Cretaceous reversal sequence. Geology, 2:

1975b. Reversed events within the Late Cretaceous normal polarity interval. EOS, Trans. Am. Geophys. Union, 56:354.

LaBrecque, J. L., Kent, D. V., and Cande, S. C., 1977. Revised magnetic polarity time scale for the Late Cretaceous and Cenozoic. Geology, 5, 330-335.

Lindsay, E. H., Butler, R. F., and Johnson, N. M., 1981. Magnetic polarity zonation and biostratigraphy of Late Cretaceous and $\mathrm{Pa}$ leocene continental deposits, San Juan, New Mexico. Am. J. Sci., 281:390-435.

Lowrie, W., and Alvarez, W., 1977. Upper Cretaceous Paleogene magnetic stratigraphy at Gubbio Italy, III Upper Cretaceous magnetic stratigraphy. Geol. Soc. Am. Bull., 88:374-377.

Lowrie, W., Alvarez, W., Premoli Silva, I., and Monechi, S., 1980. Lower Cretaceous magnetic stratigraphy in Umbrian pelagic carbonate rocks. Geophys. J. Roy. Astron. Soc., 60:263-281.

Ness, G., Levi, S., and Couch, R., 1980. Marine magnetic anomaly time scale for the Cenozoic and Late Cretaceous: A precis, critique and synthesis. Rev. Geophys. Space Phys., 18:753-770.

Date of Initial Receipt: November 10, 1982

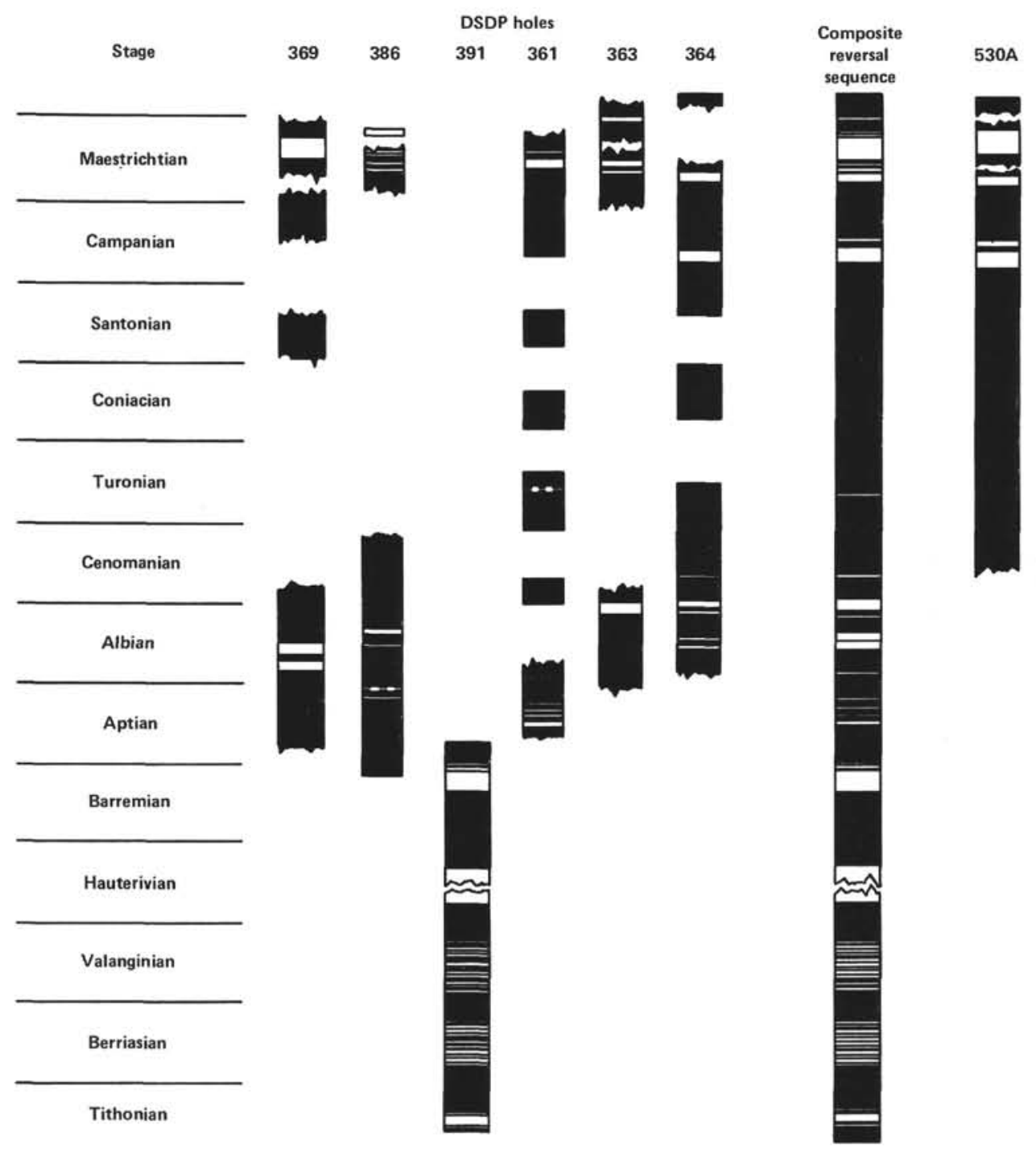

Figure 6. Summary of paleomagnetic studies of Cretaceous sediments from DSDP Legs 40, 41, 43, 44, and 75 . Within the polarity summary columns, black represents normal polarity and white represents reversed polarity. The composite polarity summary column is drawn on the basis of the results from Legs $40,41,43$, and 44 and those reported by Keating (1976). 